\title{
Supercritical Fluid Extraction of Pyrrolidine Alkaloid from Leaves of Piper amalago $\mathbf{L}$.
}

\author{
V. S. Carrara, ${ }^{1}$ L. C. Filho, ${ }^{1}$ V. A. S. Garcia, ${ }^{1}$ V. S. Faiões, ${ }^{2}$ E. F. Cunha-Júnior, ${ }^{2}$ \\ E. C. Torres-Santos, ${ }^{2}$ and D. A. G. Cortez ${ }^{3}$ \\ ${ }^{1}$ Department of Chemical Engineering, State University of Maringá, 87020-900 Maringá, PR, Brazil \\ ${ }^{2}$ Laboratory of Biochemistry of Trypanosomatids, Oswaldo Cruz Institute, FIOCRUZ, 21040-360 Rio de Janeiro, RJ, Brazil \\ ${ }^{3}$ Department of Pharmacy, State University of Maringá, 87020-900 Maringá, PR, Brazil
}

Correspondence should be addressed to V. S. Carrara; vanessa-carrara@hotmail.com

Received 16 December 2016; Revised 1 March 2017; Accepted 22 March 2017; Published 2 May 2017

Academic Editor: Vincenzo De Feo

Copyright (C) 2017 V. S. Carrara et al. This is an open access article distributed under the Creative Commons Attribution License, which permits unrestricted use, distribution, and reproduction in any medium, provided the original work is properly cited.

\begin{abstract}
Supercritical fluid extraction was used to extract the alkaloid $N$-[7-( $3^{\prime}, 4^{\prime}$-methylenedioxyphenyl)-2(Z),4(Z)-heptadienoyl]pyrrolidine from leaves of Piper amalago L. A three-level orthogonal array design matrix, $\mathrm{OAD} \mathrm{OA}_{9}\left(3^{4}\right)$, was used for optimization of the parameters of supercritical extraction of the alkaloid, employing supercritical carbon dioxide: extraction time $(20,40$, and $60 \mathrm{~min}$ ), temperature $\left(40,50\right.$, and $\left.60^{\circ} \mathrm{C}\right)$, pressure $(150,200$, and $250 \mathrm{bar}$ ), and the use of cosolvents (ethanol, methanol, and propyleneglycol). All parameters had significant effect on the alkaloid yield. The alkaloid yield after 60 min of extraction without cosolvents at 9 different conditions $\left(3^{2}\right)$ in terms of temperature $\left(40,50\right.$, and $\left.60^{\circ} \mathrm{C}\right)$ and pressure $(150,200$, and 250 bar) was also evaluated. The optimal yield $\left(\approx 3.8 \mathrm{mg} \mathrm{g}^{-1}\right)$ was obtained with supercritical $\mathrm{CO}_{2}+$ methanol $(5 \% \mathrm{v}: \mathrm{v})$ at $40^{\circ} \mathrm{C}$ and 200 bar for $60 \mathrm{~min}$ of extraction.
\end{abstract}

\section{Introduction}

Piper amalago L. (Piperaceae) is a shrub that spans a height of 2-7 m, distributed from Mexico to the south of Brazil. Popularly known as jaborandi-manso, it is traditionally used to treat heart problems, like hypertension, burns, inflammation $[1,2]$, and infections $[3,4]$. The infusion of leaves is typically used to relieve intestinal colic [5], stomachaches [3], and muscle aches [6]. The alcoholature of the leaves is used during the bath to hydrate and treat the loss of hair [6]. The infusions of the roots are used as diuretic and against renal stones [5]. Pharmacological investigations have also shown that the extracts from $P$. amalago leaves present anti-inflammatory [7], anxiogenic [8], diuretic, natriuretic, antilithiatic [9], healing [10], schistosomicidal [11], and antileishmanial activities [12].

The chemical components recently found in leaves of this plant are (1) $N$-[7-( $3^{\prime}, 4^{\prime}$-methylenedioxyphenyl)$2(Z), 4(Z)$-heptadienoyl]pyrolidine, (2) N-[7- $\left(3^{\prime}, 4^{\prime}\right.$-methylenedioxyphenyl)-2(E),4(E)-heptadienoyl]pyrrolidine [12],
(3) N- [3-( $6^{\prime}$ - methoxy-3', $4^{\prime}$-(methylenedioxyphenyl)-2(Z)propenoyl $]$ pyrrolidine, (4) $\mathrm{N}$-[3-(6 $6^{\prime}$-methoxy-3', $4^{\prime}$-methylenedioxyphenyl)-2(E)-propenoyl]pyrrolidine [10], (5) lupeol, and (6) vitexin [13].

The compound $1 \mathrm{~N}$-[7-( $3^{\prime}, 4^{\prime}$-methylenedioxyphenyl)$2(Z), 4(Z)$-heptadienoyl]pyrrolidine has showed important antifungal [14], antileishmanial [15], and schistosomicidal activities [11] and has been found in considerable quantity in leaves of $P$. amalago L. The alkaloid 2 showed antileishmanial activity. Pyrrolidine alkaloids $\mathbf{1}$ and 2, which have been related to benefic effects of $P$. amalago L., are soluble in chloroform and dichloromethane, which are toxic to the health human and environment. Therefore, the extraction using clean technology is indispensable. In this sense, supercritical fluid extraction is safer for the human being, due to the reduction of the volume of organic solvent and extraction time [16]. Authors have been extracting alkaloids semipurified by supercritical fluid extraction [17-19], and we have extracted the pyrrolidine alkaloids with better yield than chloroform [12]. Considering the important biological 
TABLE 1: Orthogonal array design matrix $\mathrm{OAD} \mathrm{OA}_{9}(3)^{4}$ and experimental results of alkaloid $\mathbf{1}$ yield.

\begin{tabular}{|c|c|c|c|c|c|}
\hline \multirow{2}{*}{ Run } & \multicolumn{4}{|c|}{ Factors } & \multirow{2}{*}{$\begin{array}{c}\text { Responses } \\
Y_{\mathrm{Ap}} \pm \sigma_{\mathrm{p}}\left(\mathrm{mgg}^{-1}\right)(n=3)\end{array}$} \\
\hline & Cosolvent & $t(\min )$ & $T\left({ }^{\circ} \mathrm{C}\right)$ & $P$ (bar) & \\
\hline 1 & Ethanol & 20 & 40 & 150 & $0.29 \pm 0.02$ \\
\hline 2 & Ethanol & 40 & 50 & 200 & $1.2 \pm 0.3$ \\
\hline 3 & Ethanol & 60 & 60 & 250 & $1.59 \pm 0.07$ \\
\hline 4 & Methanol & 20 & 50 & 250 & $1.0 \pm 0.3$ \\
\hline 5 & Methanol & 40 & 60 & 150 & $0.7 \pm 0.9$ \\
\hline 6 & Methanol & 60 & 40 & 200 & $3.8 \pm 0.8$ \\
\hline 7 & Propyleneglycol & 20 & 60 & 200 & $1.9 \pm 0.3$ \\
\hline 8 & Propyleneglycol & 40 & 40 & 250 & $1.86 \pm 0.08$ \\
\hline 9 & Propyleneglycol & 60 & 50 & 150 & $0.73 \pm 0.01$ \\
\hline
\end{tabular}

$Y_{\mathrm{Ap}}=$ yield of the alkaloid in the plant.

Results are expressed as mean \pm standard deviation $(\sigma)$.

TABLE 2: Analysis of variance (ANOVA) of four parameters for the extraction using supercritical $\mathrm{CO}_{2}$ and cosolvents.

\begin{tabular}{lcccccc}
\hline & Sum of squares & Degrees of freedom & $F$-ratio & $F_{0.05}$ & $p$ value & Effect \\
\hline Cosolvent & 2.3 & 2 & 1.1 & 7.4 & 0.01 & Significant \\
Time & 3.1 & 2 & 1.5 & 10.0 & 0.005 & Significant \\
Temperature & 3.1 & 2 & 1.6 & 10.0 & 0.005 & Significant \\
Pressure & 8.3 & 2 & 4.1 & 26.6 & 0.0002 & Significant \\
Residual & 1.4 & 9 & 0.15 & & \\
\hline
\end{tabular}

activities of compound $\mathbf{1}$, it is indispensable to evaluate the factors which influence its extraction using supercritical carbon dioxide.

Therefore, the objective of the present work was to identify and evaluate the previous operational parameters involved in the process of the extraction of alkaloid $\mathbf{1}$ from leaves of $P$. amalago L. using supercritical carbon dioxide. The methodology used was a four-level three factor orthogonal array design (OAD) with an $\mathrm{OA}_{9}(3)^{4}$ matrix, considering the following parameters: cosolvents, time of extraction, temperature, and pressure [20, 21]. Moreover, extractions employing only carbon dioxide $\mathrm{CO}_{2}$ using the planning by blocking were also studied.

\section{Materials and Methods}

2.1. Plant Material. Piper amalago L. leaves ( $2 \mathrm{~kg})$ were collected from the Bosque II, Maringá, Paraná, Brazil, whose voucher specimen (number HUEM 9885) was deposited in the herbarium of the Department of Botany, State University of Maringá. Leaves were dried in an air circulating oven (Quimis ${ }^{\circledR}$, model Q-31) for three days and crushed in a knife grinder (Tecnal Marconi ${ }^{\circledR}$, model TE 048, Piracicaba, Brazil). Particles with medium diameter of $0.757 \mathrm{~mm}$ were used for preparation of the extracts using supercritical carbon dioxide with or without cosolvents.

2.2. Purification of the Alkaloid. The isolation of the alkaloid N[7-( $3^{\prime}, 4^{\prime}$-methylenedioxyphenyl)-2(Z),4(Z)-heptadienoyl]pyrrolidine (compound 1) from $P$. amalago $L$. leaves and its spectral data were described in a previous study [12].
2.3. Extraction Using Supercritical Carbon Dioxide. The experiments were performed with the following equipment: $\mathrm{CO}_{2}$ reservoirs (both technical grade obtained from White Martins ${ }^{\circledR}$, Rio de Janeiro, Brazil), two thermostatic baths, a syringe pump (Teledyne Isco ${ }^{\circledR}$, model 500D, Lincoln, USA) and an extractor with dimensions of $17 \times 2 \mathrm{~cm}$, an absolute pressure transducer (Smar ${ }^{\circledR}$, model LD 301, São Paulo, Brazil) equipped with a portable program (Smar, model HT 201, São Paulo, Brazil) with an accuracy of $\pm 0.031 \mathrm{MPa}$, a micrometric valve, and amber glass bottles as collectors. The extractor was loaded in a random way with approximately $12 \mathrm{~g}$ of noncompact powdered sample. The extraction parameters of compound were performed by orthogonal array design (OAD) $\mathrm{OA}_{9}\left(3^{4}\right)$ (Table 1) [16]. In the present work, four factors were studied by a three-level OAD: modifiers, dynamics extraction time, temperature, and pressure. The effects of the parameters on the yield of compound 1 were studied by analysis of variance (ANOVA). The flow rate used for the extractions was $3 \mathrm{~mL} / \mathrm{min}$ with $5 \%$ of cosolvent $(\mathrm{v} / \mathrm{v})$. The powder particle diameter was $0.757 \mathrm{~mm}$. All the conditions were realized in triplicate. Extractions employing only $\mathrm{CO}_{2}$ were also studied using the planning by blocking, according to Table 2, with the central point $50^{\circ} \mathrm{C}, 200$ bar. The flow rate of $\mathrm{CO}_{2}$ was $3 \mathrm{~mL} / \mathrm{min}$ and the time of dynamic extraction was $60 \mathrm{~min}$. All the experiments were done in triplicate.

2.4. HPLC Analysis. Extracts were analyzed by High Performance Liquid Chromatography, according to a validated method. The equipment used was as follows: using a Gilson 321 Binary HPLC Pump (Middleton, WI, USA) equipped with a manual injection valve with a loop of $20 \mu \mathrm{l}$, Gilson 864 
degasser, and a Gilson $152 \mathrm{UV} /$ visible detector (Middleton, WI, USA), controlled by Borwin version 1.5 Software (Easton, MD, USA). The chromatographic analysis was carried out in a Kinetex C18 column $(150 \times 4,6 \mathrm{~mm}$, d.i. $)$ Phenomenex ${ }^{\circledR}$, packed with $5 \mu \mathrm{m}$ particles at $25^{\circ} \mathrm{C}$. The mobile phase used was $58 \%$ of acetonitrile and $42 \%$ of water containing $1 \%$ of acetic acid for $6 \mathrm{~min}$, changing to $100 \%$ of acetonitrile at $7 \mathrm{~min}$ to $11 \mathrm{~min}$, returning to $58 \%$ of acetonitrile and $42 \%$ of water at $11 \mathrm{~min}$ to $12 \mathrm{~min}$, at flow rate of $1 \mathrm{ml} / \mathrm{min}$. The alkaloid was detected at $260 \mathrm{~nm}$. The solutions of the extracts were prepared in acetonitrile at $300 \mu \mathrm{g} / \mathrm{ml}$ and filtered through a nonsterile $0.45 \mu \mathrm{m}$ membrane filter (Millipore ${ }^{\circledR}$, São Paulo, Brazil). A volume of $20 \mu \mathrm{l}$ of each sample was manually injected into the HPLC, and the analysis was carried out in triplicate. The data were evaluated by the software Statistica ${ }^{\circledR}$ 6.0. In order to evaluate the alkaloid content in the extracts, a curve of calibration was carried out by the external standard method, using alkaloid $\mathbf{1}$ isolated previously as standard. A stock standard solution of $1000 \mu \mathrm{g} / \mathrm{ml}$ in acetonitrile was prepared and diluted to the following concentrations: 15,45 , 100,150 , and $200 \mu \mathrm{g} / \mathrm{ml}$. The analyses were carried out in triplicate. The calibration function was $y=30344+63869$. The coefficient of determination for the linear regression was calculated as $r^{2}=0.999$. The relative standard deviation was lesser than $5 \%$ and the accuracy was above $98 \%$ for all concentrations.

\section{Results and Discussion}

3.1. Chromatograms Obtained. Carbon dioxide and cosolvents at supercritical conditions were used to have extracts from $P$. amalago L. leaves containing the pyrrolidine alkaloid. As already explained, the purpose was to evaluate the effect of factors, which are usually important in an operation of extraction, on alkaloid yield. An example of chromatogram that reveals the presence of the pyrrolidine alkaloid in the examined extracts and the chromatogram of a standard solution with pure pyrrolidine are presented in Figure 1.

3.2. Study of the Operational Parameters Involved in the Extraction of Alkaloid 1 by $\mathrm{OAD} \mathrm{OA}_{9}(3)^{4}$. The experimentation planning and the data obtained for the alkaloid extraction are shown in Table 1. The data were analyzed using Statistica 6.0 program for evaluating the effect of each parameter on the extraction of the compound 1 . The data of the analysis of variance (ANOVA) of this study are shown in Table 2. The relation between the yield of the alkaloid and the different factors is shown in Figure 2.

The amount of the compound 1 ( $2.03 \mathrm{mg} \cdot \mathrm{g}^{-1}$ of the plant) was also evaluated in the chloroform extract, which was obtained by the remaceration method.

The effect of cosolvents was evaluated. Considering the alkaloid an intermediate polarity compound, ethanol, methanol, and propyleneglycol were used as polar modifiers in the extraction by supercritical $\mathrm{CO}_{2}$, with the view to verify the effect of each one on the alkaloid yield. The cosolvents related have been shown to improve the efficiency of the alkaloids extraction and reduce the extraction time. According to the results shown in Figure 2 and Table 1, the yield of the alkaloid was significantly affected by the change of the modifiers. The mean yield varied from 1 to $2 \mathrm{mg} \cdot \mathrm{g}^{-1}$, with the minimum value obtained with ethanol and the maximum when using methanol as cosolvent. Other authors also concluded that the methanol was the best cosolvent used to improve the yield of the extraction of the alkaloids and amides [22-24]. The yield of the extraction of the compound $\mathbf{1}\left(2 \mathrm{mg} \cdot \mathrm{g}^{-1}\right)$ was similar to that obtained by chloroform extraction. However, the supercritical fluid extraction employing methanol as cosolvent used less solvent.

The time of extraction (Figure 2 and Table 2) influenced significantly the yield of the alkaloid, which varied around from 1 to $2.05 \mathrm{mg} \cdot \mathrm{g}^{-1}$, obtaining the highest yield in $60 \mathrm{~min}$. Therefore, it takes about an hour to obtain the analyte of the interest with efficiency, without overspending wasting. Studies about supercritical fluid extraction of the alkaloids and amides using carbon dioxide have shown a time of $60 \mathrm{~min}$ to obtain an optimal yield of the analytes [19, 23, 25]. The quantity of alkaloid 1 extracted for $60 \mathrm{~min}$ was similar to the yield obtained by the remaceration method for three days. Considering that the efficiency of the extraction is related to quantity of the solvent and time employed, compound 1 was extracted with more effectiveness in less time.

Figure 2 and Table 2 showed the effect of the temperature on the yield of the alkaloid. The yield varied at range from 0.96 to $2.00 \mathrm{mg} \cdot \mathrm{g}^{-1}$, with the temperature of $40^{\circ} \mathrm{C}$ being the most appropriate to extract the analyte. The increasing of the temperature to $50^{\circ} \mathrm{C}$ led to the lowest yield. Compound 1 was extracted in medium conditions compared to the other alkaloids extracted at higher temperatures [19, 26-29]. The study showed that temperature higher than $25^{\circ} \mathrm{C}$ is needed to extract alkaloid $\mathbf{1}$ with the similar yield of the compound obtained by the chloroform extraction.

Different values of pressure, 150, 200, and 250 bar, were employed to analyze the effect of the pressure on the yield to the alkaloid. Figure 2 and Table 2 showed that the pressure influenced the alkaloid yield significantly, with the mean ranging between 0.70 and $2.30 \mathrm{mg}^{-1} \mathrm{~g}^{-1}$. The analyte was extracted with the increasing of the pressure, obtaining the highest yield with the pressure of 200 bar. The yield of the extraction of compound $1\left(2.30 \mathrm{mg} \cdot \mathrm{g}^{-1}\right)$ was better than yield of the compound obtained by the chloroform extraction. Alkaloids have been extracted with temperature and pressure above $50^{\circ} \mathrm{C}$ and 200 bar, respectively [19, 26-29]. In the present work, the pyrrolidine alkaloids were extracted with mild conditions of temperature and pressure $\left(40^{\circ} \mathrm{C}, 200 \mathrm{bar}\right)$. Therefore, the densities of the carbon dioxide were according to the literature.

3.3. Study of the Operational Parameters Involved in the Extraction of Alkaloid 1 by Planning for Blocking. In order to certify if the modifier contributed to the efficiency of the extraction, nine conditions of extractions were studied, using supercritical $\mathrm{CO}_{2}$ in the absence of cosolvents under different temperatures and pressures. The planning by blocking was used for the experiments, with the central point $\left(50^{\circ} \mathrm{C}, 200\right.$ bar) carried out in triplicate. The flow rate of supercritical 


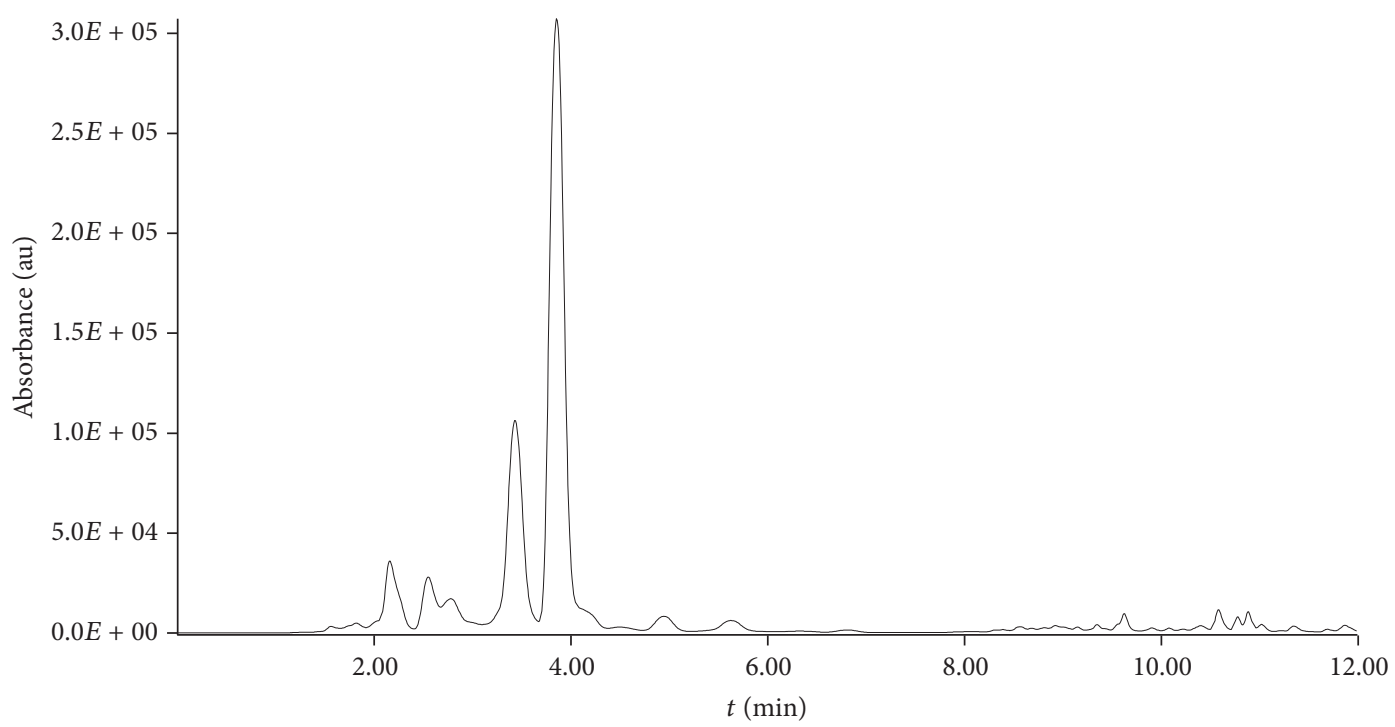

(a)

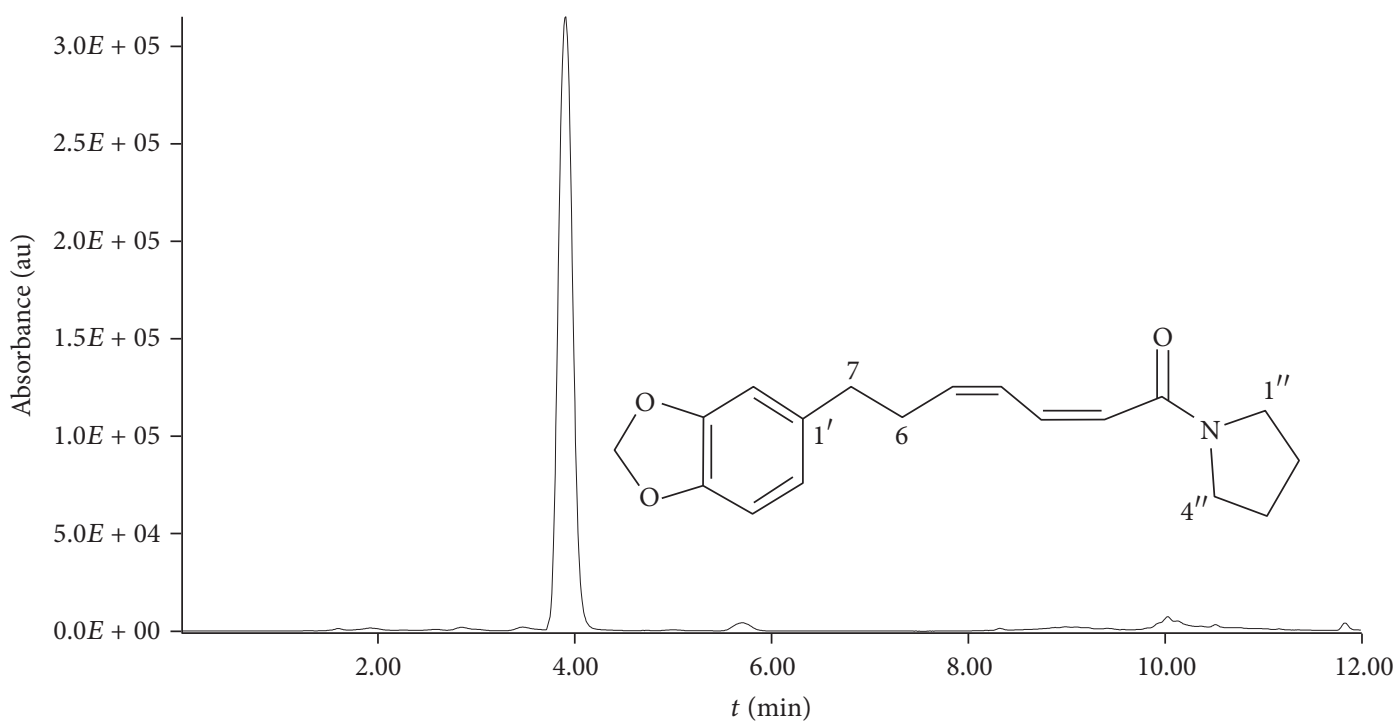

(b)

FIgURE 1: (a) Chromatogram of an extract obtained by supercritical $\mathrm{CO}_{2}+5 \%$ methanol (v: v) at $40^{\circ} \mathrm{C}, 200$ bar for 60 min. (b) Chromatogram of the examined alkaloid whose retention time was $4 \mathrm{~min}$. Chromatograph conditions: column Kinetex C18 column Phenomenex $(150 \times$ $4.6 \mathrm{~mm}$, d.i.), at $25^{\circ} \mathrm{C}$; mobile phase used was $58 \%$ of acetonitrile and $42 \%$ of water containing $1 \%$ of acetic acid, changing to $100 \%$ of acetonitrile at $7 \mathrm{~min}$ to $11 \mathrm{~min}$, returning to $58 \%$ of acetonitrile and $42 \%$ of water at $11 \mathrm{~min}$ to $12 \mathrm{~min}$, flow rate of $1 \mathrm{ml} / \mathrm{min}$; temperature at $25^{\circ} \mathrm{C}$; detection at $260 \mathrm{~nm}$.

$\mathrm{CO}_{2}$ was about $3 \mathrm{~mL} / \mathrm{min}$, and the time of extraction was $60 \mathrm{~min}$ in the conditions.

The yield of alkaloid 1 at such conditions is presented in Table 3. The data showed that the yield of the alkaloid was higher $(1.11 \pm 1.60 \mathrm{mg} / \mathrm{g})$ at $60^{\circ} \mathrm{C}, 250 \mathrm{bar}$, and $60 \mathrm{~min}$ of extraction. All extractions using only supercritical $\mathrm{CO}_{2}$ led to less yields of the alkaloid than the extractions employing supercritical $\mathrm{CO}_{2}$ more cosolvents. Alkaloids are compounds with intermediate polarity and have little solubility in carbon dioxide. Modifiers must be added to improve the extraction, and methanol was the better cosolvent in this study.
Therefore, the condition of extraction that resulted in the highest alkaloid content $\left(Y_{\mathrm{Ap}}=3.8 \pm 0.8 \mathrm{mg} \mathrm{g}^{-1}\right)$ was supercritical $\mathrm{CO}_{2}$ at $40^{\circ} \mathrm{C}, 200$ bar, cosolvent methanol 5\%, $60 \mathrm{~min}$ of extraction, and flow rate of $3 \mathrm{~mL} / \mathrm{min}$. Additionally, the extraction efficiency of compound 1 obtained was higher than that obtained by chloroform extraction.

\section{Conclusions}

Different conditions of extraction were employed with the objective of studying the effect of them on the alkaloid yield of $P$. amalago L. All parameters affect the alkaloid yield. 


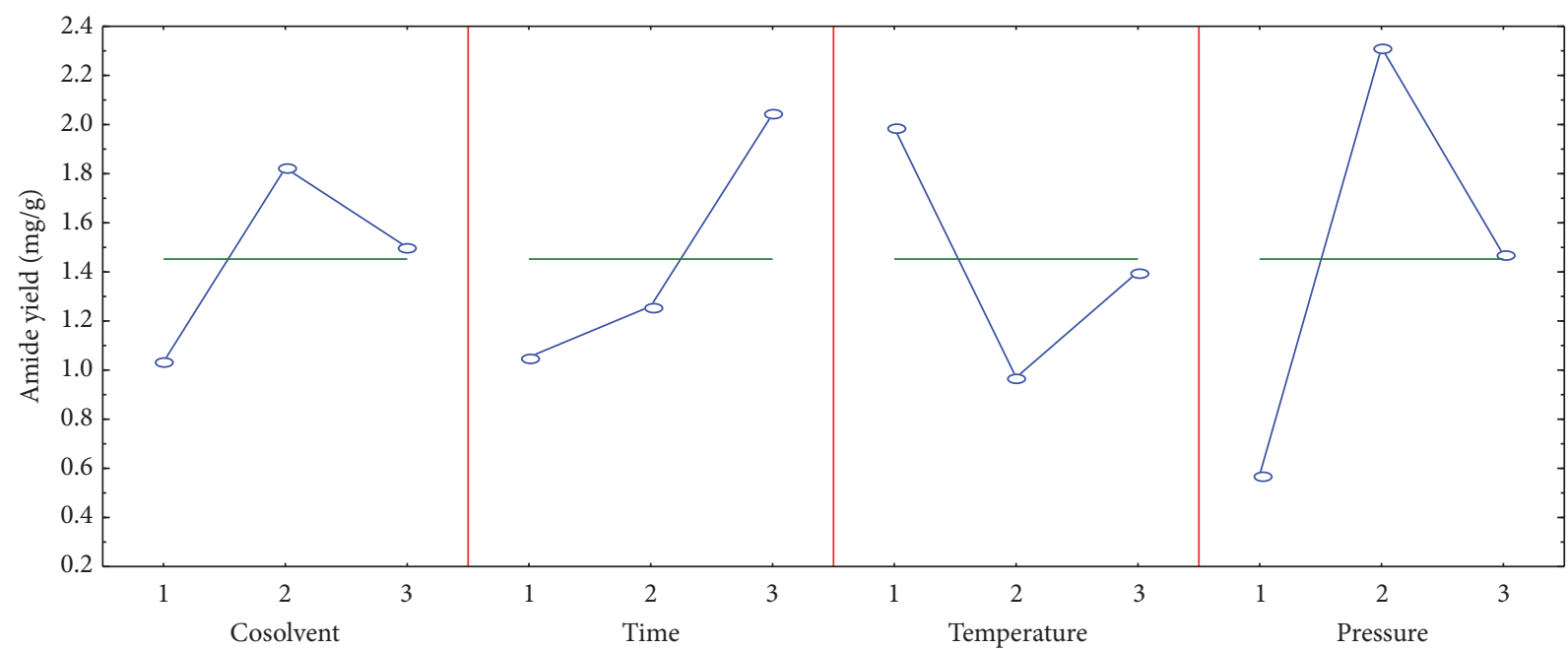

FIGURE 2: The effect of the parameters on the alkaloid yield. Cosolvent $(1=$ ethanol, $2=$ methanol, and $3=$ propyleneglycol $)$; time $(1=20 \mathrm{~min}$, $2=40 \mathrm{~min}$, and $3=60 \mathrm{~min})$; temperature $\left(1=40^{\circ} \mathrm{C}, 2=50^{\circ} \mathrm{C}\right.$, and $\left.3=60^{\circ} \mathrm{C}\right)$; pressure $(1=150 \mathrm{bar}, 2=200 \mathrm{bar}$, and $3=250 \mathrm{bar})$. The error bar shows standard deviations for $n=3$.

TABLE 3: Alkaloid yield for extraction without cosolvents (only $\left.\mathrm{CO}_{2}\right)$ at different pressures and temperatures $(t=60 \mathrm{~min})$.

\begin{tabular}{lccc}
\hline Run & Factors & $\begin{array}{c}\text { Responses } \\
Y_{\mathrm{Ap}}\left(\mathrm{mg} \mathrm{g}^{-1}\right) \pm \sigma_{\mathrm{Rp}}(\%)\end{array}$ & $0.42 \pm 1$ \\
\hline 10 & $T\left({ }^{\circ} \mathrm{C}\right)$ & $P(\mathrm{bar})$ & $0.54 \pm 2$ \\
11 & 40 & 150 & $0.48 \pm 2$ \\
12 & 50 & 150 & $0.97 \pm 3$ \\
13 & 60 & 150 & $0.90 \pm 12$ \\
14 & 40 & 200 & $1.04 \pm 2$ \\
15 & 50 & 200 & $0.75 \pm 2$ \\
16 & 60 & 200 & $0.71 \pm 1$ \\
17 & 40 & 250 & $1.11 \pm 2$ \\
18 & 50 & 250 & 250 \\
\hline
\end{tabular}

$Y_{\mathrm{Ae}}=$ yield of the alkaloid in the extract. $Y_{\mathrm{Ap}}=$ yield of the alkaloid in the plant.

Results are expressed as mean \pm relative standard deviation $\left(\sigma_{\mathrm{R}}\right)$.

Cosolvents contributed significantly with the efficiency of the extraction of the alkaloid. Results indicated that the highest alkaloid content (run 6 in Table $1, Y_{\mathrm{Ap}}=3.8 \pm 0.8 \mathrm{mgg}^{-1}$ ) was obtained employing the following extract conditions: the higher time $(60 \mathrm{~min})$ of extraction and mild conditions of temperature and pressure $\left(40^{\circ} \mathrm{C}, 200 \mathrm{bar}\right)$ and methanol as cosolvent. To the best of our knowledge, this is the first study about the extraction parameters of the pyrrolidine alkaloid from this plant. The present work may be used with reference to the additional studies to discover the optimal extraction conditions of all alkaloids in the plant.

\section{Conflicts of Interest}

The authors declare that they have no conflicts of interest.

\section{Acknowledgments}

The authors are grateful to CNPq, CAPES, FAPESP, and FUNDAÇÃO ARAUCÁRIA for providing a research grant and fellowships.

\section{References}

[1] V. L. P. Dos Santos, C. R. C. Franco, E. Amano, I. J. MessiasReason, and J. M. Budele, "Anatomical investigations of Piper amalago (Jaborandi-manso) for the quality control," Brazilian Journal of Pharmacognosy, vol. 25, no. 2, pp. 85-91, 2015.

[2] V. S. Parmar, S. C. Jain, K. S. Bisht et al., "Phytochemistry of the genus Piper," Phytochemistry, vol. 46, no. 4, pp. 597-673, 1997.

[3] A. S. Novaes, J. S. Mota, and M. E. Barros, "Estudo bibliográfico sobre possível atividade antilitiásica de Piper amalago (Piperaceae)," in 10 Simposio Brasil-Japão, pp. 1-4, Campo Grande, Brazil, 2010.

[4] E. Heckel, Les Plantes Médicinales et Toxiques de la Guyane Française, Protat Freres, Macon, France, 1897.

[5] J. da Silva Mota, D. S. de Souza, C. V. Boone, C. A. Lima Cardoso, and E. Bastos Caramão, "Identification of the volatile compounds of leaf, flower, root and stem oils of Piper amalago (Piperaceae)," Journal of Essential Oil-Bearing Plants, vol. 16, no. 1, pp. 11-16, 2013.

[6] M. Bonson, Levantamento Etnobotânico de Plantas Medicinais Nativas Utilizadas Pela População dos Municípios de São Pedro do Iguaçu e Vera Cruz do Oeste, Paraná, Brasil, Trabalho 
de Conclusão de Curso (Curso de Bacharelado em Ciências Biológicas), Pontifícia Universidade Católica do Paraná, Toledo, Spain, 2009.

[7] S. Sosa, M. J. Balick, R. Arvigo et al., "Screening of the topical anti-inflammatory activity of some Central American plants," Journal of Ethnopharmacology, vol. 81, no. 2, pp. 211-215, 2002.

[8] J. J. Lopes, C. Marx, R. Ingrassia, J. N. Picada, P. Pereira, and A. de Barros Falcão Ferraz, "Neurobehavioral and toxicological activities of two potentially CNS-acting medicinal plants of Piper genus," Experimental and Toxicologic Pathology, vol. 64, no. 1-2, pp. 9-14, 2012.

[9] A. D. S. Novaes, J. Da Silva Mota, A. Barison et al., "Diuretic and antilithiasic activities of ethanolic extract from Piper amalago (Piperaceae)," Phytomedicine, vol. 21, no. 4, pp. 523-528, 2014.

[10] R. M. Coelho, G. Brande, L. L. Ricardo et al., "Atividade cicatrizante e isolamento de amidas pirrolidínicas do extrato metanólico em Piper amalago," in 32a Reunião Anual da Sociedade Brasileira de Química, p. 1, Sociedade Brasileira de Química (SBQ), Ceará, Brazil, 2009.

[11] V. S. Carrara, S. C. H. Vieira, R. G. De Paula et al., "In vitro schistosomicidal effects of aqueous and dichloromethane fractions from leaves and stems of Piper species and the isolation of an active amide from P. amalago L. (Piperaceae)," Journal of Helminthology, vol. 88, no. 3, pp. 321-326, 2014.

[12] V. Da Silva Carrara, L. Z. Serra, L. Cardozo-Filho, E. F. CunhaJúnior, E. C. Torres-Santos, and D. A. G. Cortez, "HPLC analysis of supercritical carbon dioxide and compressed propane extracts from Piper amalago L. with antileishmanial activity," Molecules, vol. 17, no. 1, pp. 15-33, 2012.

[13] G. T. Rovani, V. L. P. dos Santos, O. G. Miguel, J. M. Budel, and R. Campos, "Phytochemical investigation of the aerial vegetative Piper amalago L.," Cadernos da Escola de Saúde, vol. 2, pp. 164177, 2013.

[14] H. M. D. Navickiene, A. C. Alécio, M. J. Kato et al., "Antifungal amides from Piper hispidum and Piper tuberculatum," Phytochemistry, vol. 55, no. 6, pp. 621-626, 2000.

[15] V. D. S. Carrara, E. F. Cunha-Júnior, E. C. Torres-Santos et al., "Antileishmanial activity of amides from Piper amalago and synthetic analogs," Brazilian Journal of Pharmacognosy, vol. 23, no. 3, pp. 447-454, 2013.

[16] H.-C. Huang, C.-M. Wei, J.-H. Siao et al., "Supercritical Fluid Extract of Spent Coffee Grounds Attenuates Melanogenesis through Downregulation of the PKA, PI3K/Akt, and MAPK Signaling Pathways," Evidence-based Complementary and Alternative Medicine, vol. 2016, Article ID 5860296, 12 pages, 2016.

[17] B. Liu, B. Shen, F. Guo, and Y. Chang, "Optimization of supercritical fluid extraction of dl-tetrahydropalmatine from rhizome of Corydalis yanhusuo W.T. Wang with orthogonal array design," Separation and Purification Technology, vol. 64, no. 2, pp. 242-246, 2008.

[18] C. G. Pereira, P. T. V. Rosa, and M. A. A. Meireles, "Extraction and isolation of indole alkaloids from Tabernaemontana catharinensis A.DC: technical and economical analysis," Journal of Supercritical Fluids, vol. 40, no. 2, pp. 232-238, 2007.

[19] J. Peng, G. Fan, and Y. Wu, "Supercritical fluid extraction of aurentiamide acetate from Patrinia villosa Juss and subsequent isolation by silica gel and high-speed counter-current chromatography," Journal of Chromatography A, vol. 1083, no. 1-2, pp. 52-57, 2005.

[20] L. Guo, S. Y. Cho, S. S. Kang, S. H. Lee, H. Y. Baek, and Y. S. Kim, "Orthogonal array design for optimizing extraction efficiency of active constituents from Jakyak-Gamcho Decoction, the complex formula of herbal medicines, Paeoniae Radix and Glycyrrhizae Radix," Journal of Ethnopharmacology, vol. 113, no. 2, pp. 306-311, 2007.

[21] C. Wang, L. Shi, L. Fan et al., "Optimization of extraction and enrichment of phenolics from pomegranate (Punica granatum L.) leaves," Industrial Crops and Products, vol. 42, no. 1, pp. 587$594,2013$.

[22] E. Ellington, J. Bastida, F. Viladomat, and C. Codina, "Supercritical carbon dioxide extraction of colchicine and related alkaloids from seeds of Colchicum autumnale L," Phytochemical Analysis, vol. 14, no. 3, pp. 164-169, 2003.

[23] B. Liu, H. Jiang, B. Shen, and Y. Chang, "Supercritical fluid extraction of sinomenine from Sinomenium acutum (Thumb) Rehd et Wils," Journal of Chromatography A, vol. 1075, no. 1-2, pp. 213-215, 2005.

[24] B. Liu, F. Guo, Y. Chang, H. Jiang, and Q. Wang, "Optimization of extraction of evodiamine and rutaecarpine from fruit of Evodia rutaecarpa using modified supercritical $\mathrm{CO}_{2}$," Journal of Chromatography A, vol. 1217, no. 50, pp. 7833-7839, 2010.

[25] E. Cassel, R. M. F. Vargas, G. W. Brun et al., "Supercritical fluid extraction of alkaloids from Ilex paraguariensis St. Hil," Journal of Food Engineering, vol. 100, no. 4, pp. 656-661, 2010.

[26] J. Y. Kim and K.-P. Yoo, "Effects of Basic Modifiers on SFE Efficiencies of Ephedrine Derivatives from Plant Matrix," Korean Journal of Chemical Engineering, vol. 17, no. 6, pp. 672-677, 2000.

[27] J. Y. Ling, G. Y. Zhang, Z. J. Cui, and C. K. Zhang, "Supercritical fluid extraction of quinolizidine alkaloids from Sophora flavescens Ait. and purification by high-speed counter-current chromatography," Journal of Chromatography A, vol. 1145, no. 12, pp. 123-127, 2007.

[28] A. Verma, K. Hartonen, and M.-L. Riekkola, "Optimisation of supercritical fluid extraction of indole alkaloids from Catharanthus roseus using experimental design methodology - Comparison with other extraction techniques," Phytochemical Analysis, vol. 19, no. 1, pp. 52-63, 2008.

[29] J. Xiao, B. Tian, B. Xie, E. Yang, J. Shi, and Z. Sun, "Supercritical fluid extraction and identification of isoquinoline alkaloids from leaves of Nelumbo nucifera Gaertn," European Food Research and Technology, vol. 231, no. 3, pp. 407-414, 2010. 


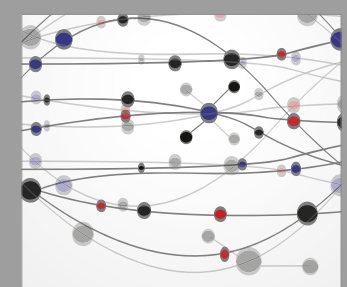

The Scientific World Journal
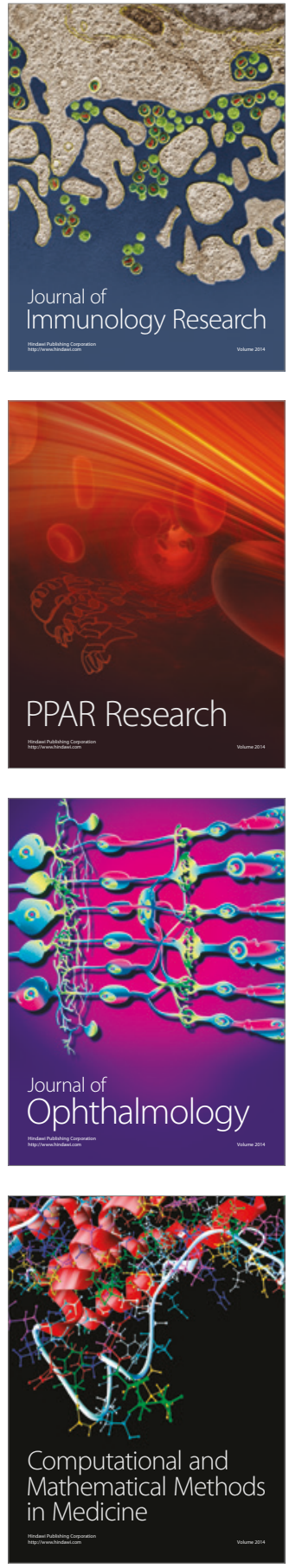

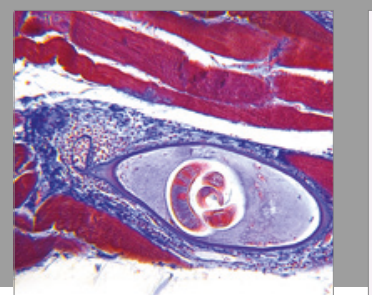

Gastroenterology Research and Practice
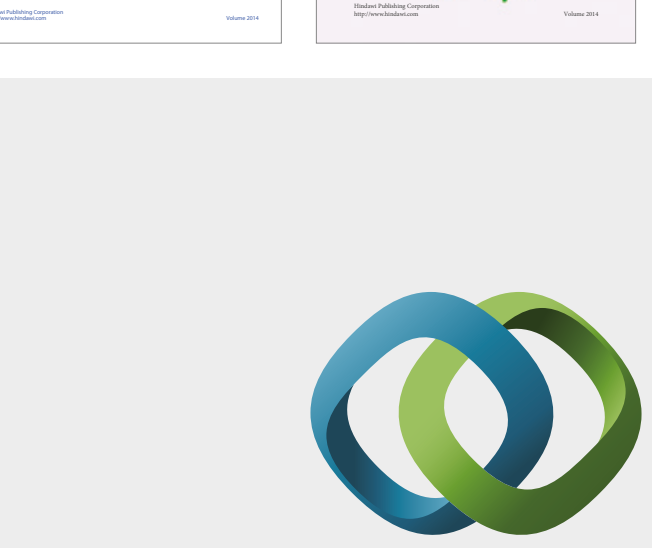

\section{Hindawi}

Submit your manuscripts at

https://www.hindawi.com
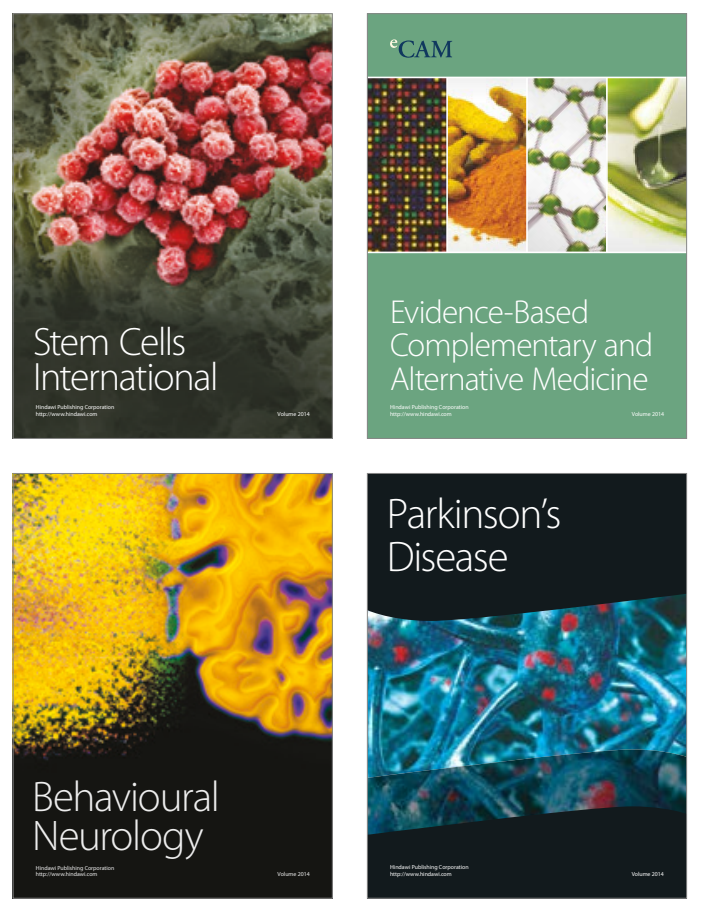
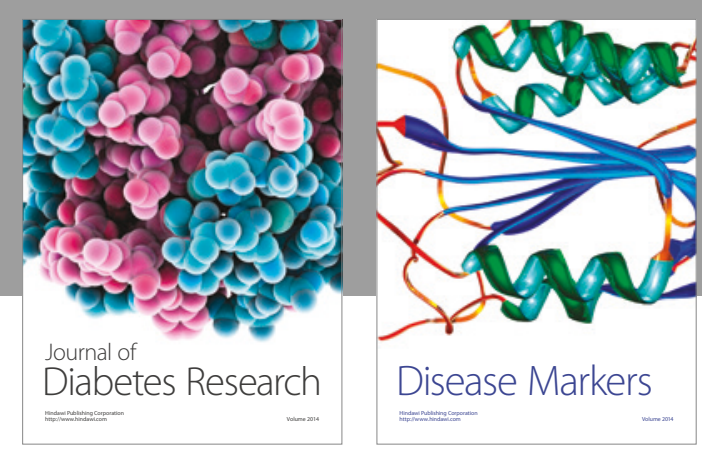

Disease Markers
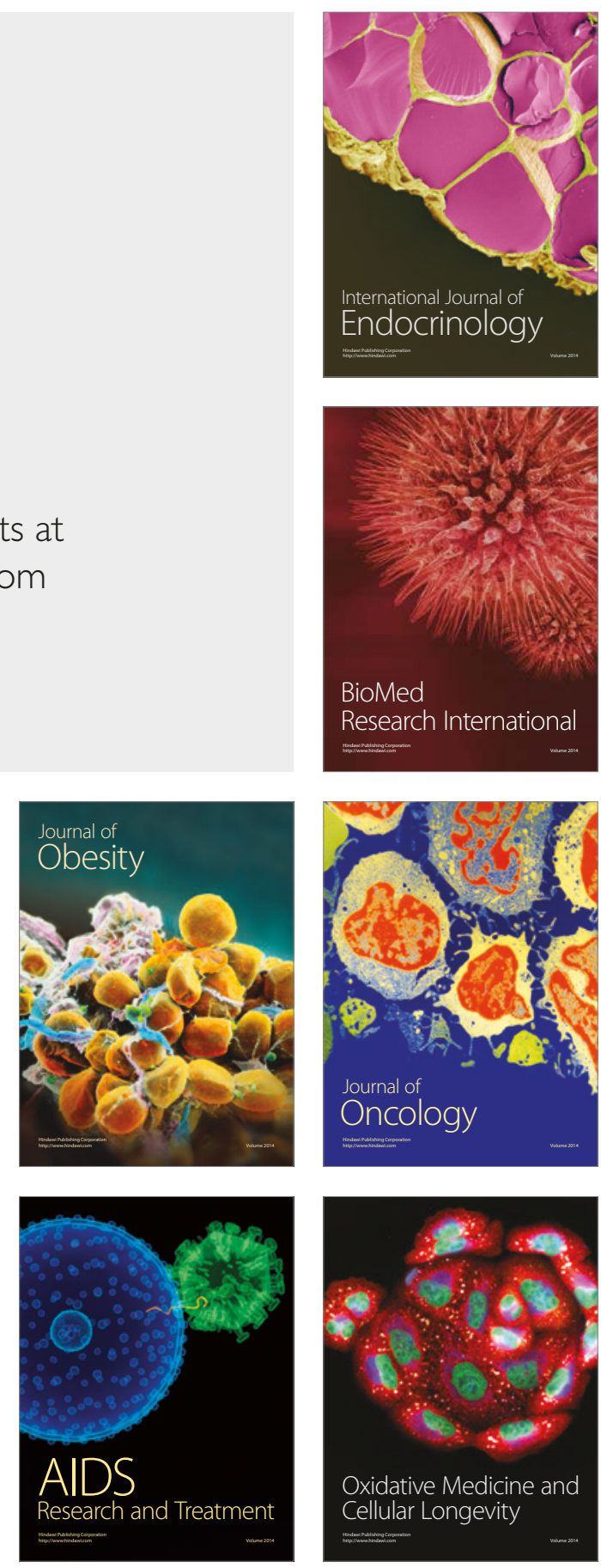